\title{
Notes on the Phylogenetic Background to Lactobacillus Taxonomy
}

\author{
By G. H. G. DAVIS \\ Department of Microbiology, University of Lagos Medical School, Lagos, Nigeria
}

(Received 29 January 1963)

SUMMARY

Speculations about the phylogeny and natural relationships of and within the genus Lactobacillus are made, based upon current taxonomic knowledge.

Phylogenetic speculation has long held a fascination for biologists who interest themselves in taxonomy and it remains to be seen whether the recent invasion of this field by computers will render this fascination fatal. The present notes are an attempt to extend certain speculations which occur in the literature. For example Davis (1955) suggested that the difficulty found in differentiating species of heterofermentative lactobacilli (see Rogosa \& Sharpe, 1959; Cheeseman \& Berridge, 1959) might indicate that these organisms are of more recent origin than the homofermenters and might be derived from them. De Ley (1962) stated 'one can thus imagine that the "heterolactic" (i.e. heterofermentative) bacteria could phylogenetically be derived from the "homolactic" (i.e. homofermentative) bacteria by the loss of aldolase and transketolase'.

Lactobacilli have been much studied and the taxonomy is comparatively well developed. The subgeneric classification proposed by Rogosa \& Sharpe (1959), with its revival of the species groups recognized by Orla-Jensen (1919), incorporates most of the recent taxonomic ideas about the genus. Newly developed analytical techniques have been successfully applied to lactobacilli and one of these, cell-wall analysis, yielded an unexpected result. Cummins \& Harris (1956) found that the homofermentative species, Lactobacillus plantarum, differed from all other known Lactobacillus species by the presence of diaminopimelic acid and absence of aspartic acid in cell-wall hydrolysates. It was subsequently found by Baddiley \& Davison (1961) that strains of $L$. plantarum also contained ribitol-teichoic acid in their cell walls, whereas other species of lactobacilli contained either glycerol-teichoic acid or none. As Baddiley \& Davison pointed out, Sharpe (1955) had found that L. plantarum strains formed a distinct serological group with only slight cross-relationship with one other group. It is possible that the latter finding reflects the former. Cummins \& Harris (1956) remarked that no other characters indicated that L. plantarum is not a typical member of the genus Lactobacillus. However, there are numerous reports of lactobacillus strains which in some character are atypical of the genus. Most of these reports are of motility, catalase production and nitrate reduction; by generic definition lactobacilli are negative in these three characters.

Vol. 34, No. 1 was issued 17 April 1964 
When taken in isolation these reports can be viewed merely as further examples of Nature's disregard of man-made classifications. When viewed as a group, however, their significance lies in the fact that strains with these atypical characters have almost invariably been classified as $L$. plantarum, variants of it or as 'atypical streptobacteria' with inferred relationship to it. Table 1 lists many of these reports.

Table 1. Reports of atypical lactobacilli

\begin{tabular}{|c|c|c|c|c|}
\hline Authors & $\begin{array}{l}\text { Source of } \\
\text { isolates }\end{array}$ & $\begin{array}{l}\text { Atypical } \\
\text { characters }\end{array}$ & $\begin{array}{c}\text { Other } \\
\text { characters }\end{array}$ & $\begin{array}{l}\text { Name and/or relation- } \\
\text { ships suggested }\end{array}$ \\
\hline $\begin{array}{l}\text { Cunningham \& Smith } \\
\text { (1940) }\end{array}$ & Silage & Motile & $\begin{array}{l}\text { Low growth temp. } \\
\text { Weak carbohydrate } \\
\text { metabolism }\end{array}$ & Streptobacterium \\
\hline $\begin{array}{l}\text { Harrison \& Hansen } \\
(1950 a, b)\end{array}$ & $\begin{array}{l}\text { Turkey } \\
\text { faeces }\end{array}$ & Motile & High growth temp. & $\begin{array}{l}\text { L. plantarum var. } \\
\text { mobilis }\end{array}$ \\
\hline $\begin{array}{l}\text { Hays \& Reister } \\
\text { (1952) }\end{array}$ & $\begin{array}{l}\text { Orange } \\
\text { juice }\end{array}$ & Motile & - & L. plantarum \\
\hline $\begin{array}{l}\text { Mann \& Oxford } \\
(\mathbf{1 9 5 4 )}\end{array}$ & Calf rumen & Motile & High growth temp. & Homofermenter \\
\hline $\begin{array}{l}\text { Deibel \& Niven } \\
\text { (1958) }\end{array}$ & Ham brine & Motile & $\begin{array}{l}\text { Low growth temp. } \\
\text { Weak carbohydrate } \\
\text { metabolism }\end{array}$ & $\begin{array}{l}\text { L. casei-plantarum } \\
\text { intermediate }\end{array}$ \\
\hline Keddie (1959) & Silage & Motile & - & $\begin{array}{l}\text { Atypical low tempera- } \\
\text { ture homofermenters }\end{array}$ \\
\hline Vankova (1957) & $\begin{array}{l}\text { Fermenta- } \\
\text { tion mash }\end{array}$ & Motile & Catalase & See text \\
\hline $\begin{array}{l}\text { Dacre \& Sharpe } \\
(\mathbf{1 9 5 6 )}\end{array}$ & Cheese & Catalase & - & L. plantarum \\
\hline Whittenbury (1960) & Various & $\begin{array}{l}\text { Catalase- } \\
\text { like }\end{array}$ & - & L. plantarum, L. brevis \\
\hline $\begin{array}{l}\text { Costilow \& } \\
\text { Humphreys (1955) }\end{array}$ & Cucumbers & Nitrate & - & L. plantarum \\
\hline Rogosa (1961) & - & Nitrate & - & $\begin{array}{l}\text { L. plantarum, } \\
\text { L. fermenti }\end{array}$ \\
\hline
\end{tabular}

About motility in lactobacilli, Harrison \& Hansen (1950a) pointed out that 'Orla-Jensen (Zentr. Bakt. Parasitensk. II, 22, 305, 1909) listed Lactobacillus as the fourth genus "Caseobacterium" in the order "Petritrichinae" indicating that, although the genus did not possess flagella, its place in his system would be among the peritrichous rather than the cephalotrichous bacteria'. Pederson(1952) identified a strain isolated by Hays \& Reister (1952) as Lactobacillus plantarum, without realizing that it was motile. Deibel \& Niven (1958) compared their isolates with previous reports and found little common ground. They concluded that their strains were intermediate between $L$. casei and $L$. plantarum, but distinct from both. In common with other workers (e.g. Harrison \& Hansen, 1950b) Deibel \& Niven isolated non-motile strains which were otherwise identical with the motile ones. The growth temperature range of motile strains appears to be variable. Lactobacillus plantarum grows at $15^{\circ}$ and often $45^{\circ}$, but Hayward (1957) noted marked variability in this character in non-motile strains and related it (see Harrison \& Hansen, 1950 b) to environmental adaptation. (Note: L. salivarius, which is usually considered as a member of the low-temperature homofermentative group, i.e. streptobacterium, grows at $45^{\circ}$ but not at $15^{\circ}$.) The motile isolates of Harrison \& Hansen and Mann \& 
Oxford (1954) (Table 1) appear to share this character. Both these reports dealt with isolates from warm-blooded animals, whereas the other reports concern isolates from saprophytic sources. The report of Vankova (1957) is unusual in several respects. The strains isolated were motile and catalase-positive and were classified as $L$. delbrueckii (thermobacterium). The detection of cytochromes $a$ and $b$ (see Deibel \& Evans, 1960) in Vankova's strains supports the suggestion of Dr M. E. Sharpe (pers. commun.) that these strains may in fact belong to the genus Bacillus. As Sharpe (1962) pointed out, there is often difficulty in distinguishing between certain Bacillus species and members of the high-temperature (thermobacterium) group of lactobacilli. To summarize these reports of motility in lactobacilli it is reasonable to say that such organisms probably occur more commonly than the records indicate in a wide range of habitats. The flagellation pattern requires more study but is probably always peritrichous. The strains do not form a homogeneous group but all resemble $L$. plantarum more closely than any other species.

Concerning catalase activity, Whittenbury (1960) described two 'catalase-like' peroxide-decomposing mechanisms found in various lactic acid bacteria. One is a strong activity, not acid-sensitive but requiring an external haemin source. This suggests that some organisms usually considered as devoid of catalase may retain the ability to synthesize the apoenzyme. Failure in prosthetic group synthesis could also account for the absence of cytochromes in these bacteria. The other activity is weaker, is acid-sensitive and does not need added haemin. The former activity occurred in certain streptobacteria, notably Lactobacillus plantarum, and certain heterofermenters, notably $L$. brevis. The latter weaker activity occurred commonly in pediococci and leuconostocs and occasionally in $L$. plantarum. It is likely that this activity was the one detected by Dacre \& Sharpe (1956). In confirming Costilow \& Humphrey's (1955) work, Rogosa (1961) found nitrate reduction in seven of twelve L. plantarum strains and two of five $L$. fermenti strains to be primarily dependent upon the $\mathrm{pH}$ value. Nitrate reduction was not detected in any other Lactobacillus species.

The regular occurrence of atypical strains closely related to Lactobacillus plantarum, together with the known characters of the species, such as its wide range of biochemical activities, relatively unexacting nutritional requirements and ubiquitous nature, lead to the present thesis, which is that $L$. plantarum and its atypical relatives represent the least specialized members of the genus and constitute a link between it and some other bacterial group, extant or otherwise. The atypical generic characters referred to above can be regarded as vestigial. It is not important whether one considers the atypical character as retrograde or advanced: the genetic potential behind them can be interpreted as vestigial in either case. On this assumption, and also assuming that the bacterial group from which the L. plantarum genotype originated is just as likely to be extant as not, it is reasonable to suggest the genus Bacillus as a convenient reservoir of biological potential from which lactobacilli, among others, may have originated (see Bisset \& Davis, 1960). Bacillus subtilis for example exhibits most if not all the characters found in L. plantarum, including the atypical characters noted in Table 1 (Knight \& Proom, 1950). Possible confusion between $B$. coagulans and certain thermobacteria on more than mere morphological grounds was noted by Sharpe (1962). Dr C. S. Cummins has pointed out that in $B$. sphaericus the vegetative form possesses cell walls which contain 
aspartic acid but no diaminopimelic acid, as in most lactobacilli, whereas the walls of the spore do contain diaminopimelic acid, as in most Bacillus species and L. plantarum (Powell \& Strange, 1957). Organisms described by Thornley \& Sharpe (1959) possessed characters apparently relating them to the genus Bacillus and to the genus Lactobacillus. Similarly, the organism known as Leptotrichia buccalis (Hamilton \& Zahler, 1957; Davis \& Baird-Parker, 1959) and those described by Theilade \& Gilmour (1961) are also of possible significance. Bisset (1962) pointed out the possible significance of certain bacterial genera such as Bacillus and Pseudomonas as the phylogenetic origins of other bacteria and the evidence quoted above conforms with this suggestion.

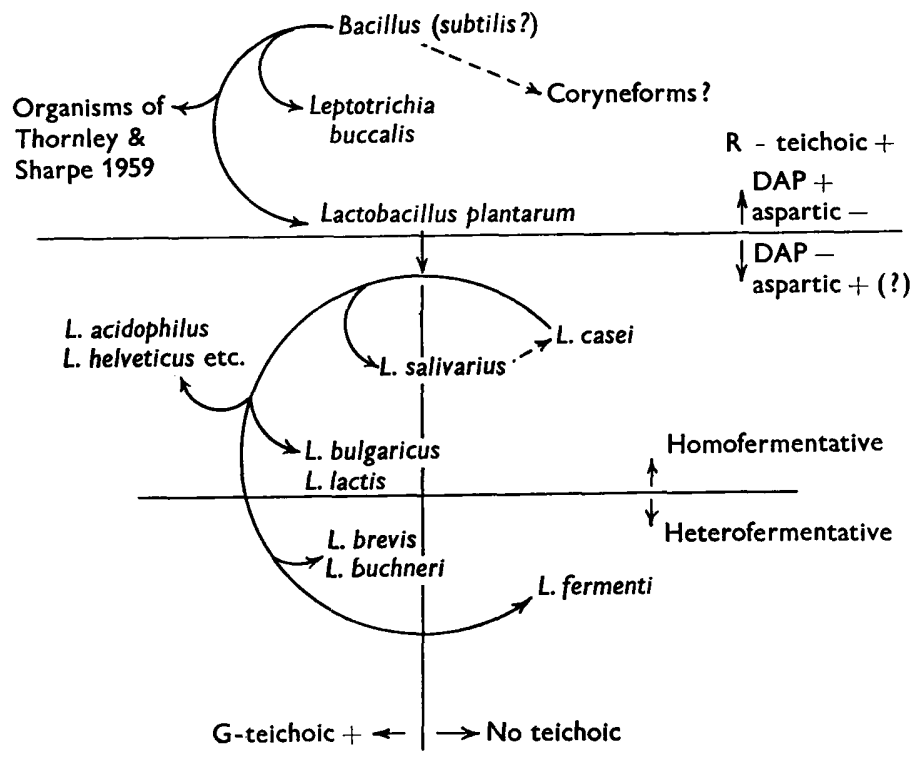

Fig. 1. Phylogenetic scheme for lactobacilli.

So far as relationships within the genus Lactobacillus are concerned, Fig. 1 shows one interpretation of the evolution of the various species. The basic assumptions of this scheme are: $(a)$ heterofermenters evolved from homofermenters; $(b)$ L. plantarum is the primitive lactobacillus. The reasoning behind Fig. 1 is that $L$. plantarum links the genera Lactobacillus and Bacillus as discussed above. The streptobacterium species, Lactobacillus casei, represents the further evolution of $L$. plantarum and the shared characters of these two species lead to their classification together as streptobacteria. Lactobacillus casei is a successful and ubiquitous species and its derivation from $L$. plantarum is quite a reasonable supposition. Lactobacillus salivarius exhibits some characters relating it to the thermobacteria, but from the evidence of Cheeseman (1959) and Keddie (1959) it is probably best considered as a high temperature streptobacterium species. As indicated in Fig. 1 it is possible that $L$. salivarius represents an offshoot of an evolutionary line leading from $L$. plantarum to the true thermobacteria. Lactobacillus salivarius certainly exhibits more characters of the streptobacteria than of the true thermobacteria, and its ability to grow at $45^{\circ}$ but not at $15^{\circ}$ probably reflects the plasticity of these characters seen in $L$. plantarum 
(see above) and leads to the next step in Fig. 1, namely the origins of the thermobacteria. This group contains a number of species, each more or less specialized to a certain habitat, and probably includes the most highly specialized versions of the homofermentative lactobacillus on the evidence of ecology and synthetic abilities. In Sharpe's (1955) serological studies the thermobacterium species $L$. lactis and $L$. bulgaricus shared a common group antigen with the betabacterium (heterofermentative) species $L$. brevis and $L$. buchneri. These four species also resemble each other in possessing glycerol teichoic acid as a cell-wall component. The production of ammonia from arginine is an almost universal character of the heterofermenters, but certain strains of $L$. brevis do not carry out this reaction, whereas certain thermobacteria (e.g. L. leichmannii and $L$. delbrueckii) are unusual in this respect and resemble betabacteria. The occurrence of a slight but definite serological relationship between $L$. plantarum and the 'lactis-brevis' group (Sharpe, 1955) provides a link between all three of the subgeneric groups and further grounds for proposing that the heterofermenters evolved via the 'plantarum-lactisbrevis' pathway. It is of interest to note that $L$. brevis resembles $L$. plantarum in fermenting pentoses; this is a fairly common character among heterofermenters but is restricted to $L$. plantarum in the homofermenters. $L$. brevis also shares with L. plantarum a degree of resistance to penicillin not found in other lactobacilli (Davis, 1959). The fact that $L$. brevis commonly shares habitats with $L$. plantarum is interesting in the present context, but also suggests that their apparent similarities may be explicable in terms of parallel evolution. Lactobacillus fermenti is probably the most successful and ubiquitous heterofermenter. It comprises a separate serological group and teichoic acid has not been detected in its cell wall. In speculations of the type outlined above there is always more than one way of interpreting available knowledge. For example, it could be argued that the thermobacteria show signs of closer relationship to the genus Bacillus than do the streptobacteria. Similarly it might be feasible to derive $L$. fermenti direct from $L$. casei.

The possible significance of atypical or vestigial characters in bacterial phylogeny is interesting and it is relevant to the present notes to mention the case of Streptococcus faecalis. Hirsch (1952) and Orla-Jensen (1943) suggested that $S$. faecalis represents the ancestor of more recently evolved streptococci, e.g. S. lactis. Catalase production and motility in $\boldsymbol{S}$. faecalis strains have been reported by Langston, Guttierez \& Bouma $(1960 a, b)$ and Steel (1962). Orla-Jensen (1943) represented his ideas about the relationships within the lactic acid bacteria in the form of a diagram with Lactobacillus plantarum in a key position and although my Fig. 1 differs considerably from Orla-Jensen's scheme the basic assumption is the same; i.e. '... it is necessary to consider these (streptobacteria) and especially Streptobacterium plantarum as the ancestors of the other lactic acid bacteria.'

The inclusion in Fig. 1 of a tentative linkage between the genera Bacillus and Corynebacterium, or coryneforms in general, should be supplemented by an equally probable linkage between Lactobacillus and coryneforms (compare 'Lactomyces' of von Magnus, 1947, and also 'Lactobacillus bifidus').

Computer taxonomy was mentioned earlier and it should be possible to test, to some extent, speculations about bacterial phylogeny, by applying statistics such as proposed by Sneath (1957). The evidence of similarity values based upon many unweighted characters is likely to be a fairly good indication of phyletic relationships. 
Differences in few characters will generally imply closeness of ancestry. Table 2 shows the results obtained after cluster analysis of similarity values calculated manually for the organisms listed. Unfortunately directly comparative information for all these organisms is not available. For example, of the sixty to seventy characters (not character states; see Sneath, 1962) for which results are available for lactobacilli, only twenty to thirty comparable results are available for Leptotrichia buccalis or the organisms of Theilade \& Gilmour (1961). It would be likewise difficult to compare lactobacilli with Bacillus or Corynebacterium species

\section{Table 2. Rearrangement of organisms after cluster analysis of $\boldsymbol{S}$-values}

\begin{tabular}{|c|c|c|c|c|c|c|c|c|c|c|c|c|c|c|c|c|}
\hline & $\mathbf{2}$ & $\mathbf{3}$ & 8 & 15 & 9 & 7 & 1 & $\mathbf{5}$ & 4 & 6 & 13 & 14 & 10 & 11 & 12 & \\
\hline 2 & - & - & - & . & . & - & - & - & - & - & • & . & - & . & . & Thornley \& Sharpe Group 2 \\
\hline 3 & 72 & & . & • & • & • & & & • & & & & & & & Thornley \& Sha \\
\hline 8 & 67 & 63 & & & . & & & & & & & & & . & . & Lactobacillus plantarum (S) \\
\hline 15 & $\mathbf{5 6}$ & $\mathbf{5 9}$ & 68 & & . & & & & & • & & & & & & Leptotrichia buccalis \\
\hline 9 & 62 & 66 & $\mathbf{5 8}$ & 56 & • & & & & & & & & & & & Lactobacillus casei $(\mathbf{S})$ \\
\hline 7 & 52 & 48 & 58 & 63 & $\mathbf{5 5}$ & - & ${ }^{\circ}$ & - & $\cdot$ & $\cdot$ & , & $\cdot$ & $\cdot$ & . & . & Lactobacillus salivarius (S) \\
\hline 1 & 62 & $\mathbf{5 5}$ & 60 & 62 & $\mathbf{5 5}$ & 58 & . & . & $\cdot$ & - & • & $\cdot$ & • & - & & Thornley \& Sharpe Group 1 \\
\hline 5 & 58 & 58 & 51 & 62 & $\mathbf{5 7}$ & 59 & 60 & $\cdot$ & • & - & & - & . & . & - & Lactobacillus acidophilus (T) \\
\hline 4 & $\mathbf{3 7}$ & 35 & 35 & $\mathbf{5 0}$ & 40 & 44 & 36 & 62 & - & ${ }^{\circ}$ & & - & . & . & . & Lactobacillus helveticus $(\mathrm{T})$ \\
\hline 6 & 42 & 41 & 36 & $\mathbf{5 7}$ & 41 & $\mathbf{4 4}$ & $\mathbf{5 0}$ & 60 & 58 & . & & & . & . & - & Lactobacillus delbrueckii (T) \\
\hline 13 & 48 & 44 & 45 & 58 & 41 & 40 & 35 & $\mathbf{3 8}$ & $\mathbf{3 7}$ & 40 & & $\cdot$ & - & & - & Lactobacillus viridescens (B) \\
\hline 14 & 46 & $\mathbf{5 0}$ & 58 & 50 & 50 & 56 & 37 & 45 & 42 & $\mathbf{3 4}$ & 50 & . & & • & & Theilade \& Gilmour \\
\hline 10 & 48 & 45 & 4,1 & 47 & 42 & 48 & $\mathbf{3 6}$ & 47 & $\mathbf{5 3}$ & $\mathbf{5 0}$ & $\mathbf{5 0}$ & 63 & . & & & Lactobacillus fermenti (B) \\
\hline 1] & 42 & 34 & $\mathbf{5 1}$ & $\mathbf{5 5}$ & 41 & 43 & $\mathbf{3 0}$ & $\mathbf{3 3}$ & $\mathbf{3 4}$ & 36 & $\mathbf{5 4}$ & 65 & 61 & & . & Lactobacillus buchneri (B) \\
\hline & 47 & 45 & 46 & 50 & 44 & 44 & 37 & 43 & 45 & 43 & $\mathbf{5 9}$ & 54 & 66 & 73 & & Lactobacillus brevis (B) \\
\hline
\end{tabular}

Figures across top and down left-hand side of Table 2 are the numbers originally allotted to the organisms listed on the right-hand side. (S) indicates streptobacterium; (T) thermobacterium; (B) betabacterium.

upon our present knowledge. In view of the known occurrence of unusual results when inadequate data are used in such analyses it would be unwise to place much reliance upon Table 2. It was not possible to construct a dendrogram from these results but three groups of elevated S-values can be detected, namely the 'fermenti-buchneri-brevis' group, the 'helveticus-delbrueckii' group, and the group comprising Lactobacillus acidophilus and the seven organisms above it. The order of the organisms in Table 2 is, however, in good agreement with the ideas put forward in these notes as a comparison between Table 2 and Fig. 1 will show.

\section{REFERENCES}

Baddiley, J. \& Davison, A. L. (1961). The occurrence and location of teichoic acids in lactobacilli. J. gen. Microbiol. 24, 295.

Bisset, K. A. \& Davis, G. H. G. (1960). The Microbial Flora of the Mouth. London: Heywood.

Bisset, K. A. (1962). The phylogenetic concept in bacterial taxonomy. In Microbial Classification. Symp. Soc. gen. Microbiol. 12, 361.

Cheeseman, G. C. \& Berringe, N. J. (1959). The differentiation of bacterial species by paper chromatography. VII. The use of electronic computation for the objective assessment of chromatographic results. J. appl. Bact. 22, 307.

Chesseman, G. C. (1959). The application of chromatographic techniques for the identification of species and strains of lactobacilli. J. appl. Bact. 22, 341. 
Costilow, R. N. \& Humphreys, T. W. (1955). Nitrate reduction by certain strains of L. plantarum. Science, 121, 168.

Cummins, C. S. \& Harris, H. (1956). The chemical composition of the cell-wall in some Gram positive bacteria and its possible value as a taxonomic character. J. gen. Microbiol. 14, 583.

Cunningham, A. \& Smith, A. M. (1940). The microbiology of silage made by the addition of mineral acids to crops rich in protein. II. The microflora. J. Dairy Res. 2, 243.

DaCre, J. C. \& Sharpe, M. E. (1956). Catalase production by lactobacilli. Nature, Lond. 178, 700 .

Davis, G. H. G. (1955). The classification of Lactobacillus strains of oral origin. Ph.D. Thesis. University of Birmingham.

DAvis, G. H. G. (1959). Lactobacilli of the human mouth. J. appl. Bact. 22, 350.

Davis, G. H. G. \& Baird-Parker, A. C. (1959). Leptotrichia buccalis. Br. dent. J. $106,70$.

DE LEY, J. (1962). Comparative biochemistry and enzymology in bacterial classification. In Microbial Classification. Symp. Soc. gen. Microbiol. 12, 164.

Deibel, R. H. \& Evans, J. B. (1960). Modified benzidine test for the detection of cytochrome containing respiratory systems in micro-organisms. J. Bact. 79, 356.

Deible, R. H. \& Nrven, C. F. (1958). Microbiology of meat curing. I. The occurrence and significance of a motile micro-organism of the genus Lactobacillus in ham curing brines. Appl. Microbiol. 6, 323.

Hamilton, R. D. \& Zahler, S. A. (1957). A study of Leptotrichia buccalis. J. Bact. 73, 386.

Harrison, A. P. \& Hansen, P. A. (1950a). A motile Lactobacillus from the cecal feces of turkeys. J. Bact. 59, 443.

Harrison, A. P. \& Hansen, P. A. (1950b). Lactobacilli from turkeys. J. Bact. 60, 543.

HAYS, G. L. \& REISTER, D. W. (1952). The control of 'off-odour' spoilage in frozen concentrated orange juice. Food Tech., Champaign, 6, 386.

Hayward, A. C. (1957). A comparison of Lactobacillus spp. from human saliva with those from other natural sources. Br. dent. $J .102,450$.

Hirsch, A. (1952). The evolution of the lactic streptococci. J. Dairy Res. 19, 290.

KEDDIE, R. M. (1959). The properties and classification of lactobacilli isolated from grass and silage. J. appl. Bact. 22, 403.

Knight, B. C. J. G. \& Proom, H. (1950). A comparative survey of the nutrition and physiology of mesophilic species of the genus Bacillus. J. gen. Microbiol. 4, 508.

Langston, C. W., Guttierez, J. \& Bouma, C. $(1960 a)$. Catalase-producing strains of streptococci. J. Bact. 80, 693.

Langston, C. W., Guttierez, J. \& Bouma, C. (1960b). Motile enterococci (Streptococcus faecium var. mobilis var.n.) isolated from grass silage. J. Bact. 80, 714 .

Magnus, R. von (1947). Biochemical activities of actinomycetes of Group IIB (Orskov) isolated from the human throat. Acta path. microbiol. scand. 24, 11.

MANN, S. O. \& OXford, A. E. (1954). Studies of some presumptive lactobacilli isolated from the rumens of young calves. J. gen. Microbiol. $2,83$.

OrLa-Jensen, S. (1919). The Lactic Acid Bacteria. Copenhagen: Andr. Fred. Host and Son.

Orla-Jensen, S. (1943). The lactic acid bacteria. Biol. Skr. Bind II, Nr. 3. Copenhagen: Ejnar Munksgaard.

Pederson, C. S. (1952). In Symposium on the Lactic Acid Bacteria. Ed. by R. P. Tittsler. Bact. Rev. 16, 227.

Powell, J. F. \& Strange, R. E. (1957). $\alpha \epsilon$-Diaminopimelic acid metabolism and sporulation in Bacillus sphaericus. Biochem. J. 65, 700.

Rogosa, M. (1961). Experimental conditions for nitrate reduction by certain strains of the genus Lactobacillus. J. gen. Microbiol. 24, 401.

Rogosa, M. \& Sharpe, M. E. (1959). An approach to the classification of the lactobacilli. J. appl. Bact. 12, 329.

Sharpe, M. E. (1955). A serological classification of lactobacilli. J. gen. Microbiol. 12, 107.

Sharpe, M. E. (1962). Taxonomy of the lactobacilli. Dairy Sci. Abstr. 24, 109. 
SNeATH, P. H. A. (1957). The application of computors to taxonomy. J. gen. Microbiol. $17,201$.

Sneath, P. H. A. (1962). The construction of taxonomic groups. In Microbial Classification. Symp. Soc. gen. Microbiol. 12, 289.

STEEL, K. J. (1962). The practice of bacterial identification. In Microbial Classification. Symp. Soc. gen. Microbiol. 12, 405.

Themlade, E. \& Gilmour, M. N. (1961). An anaerobic oral filamentous micro-organism. J. Bact. 81, 661.

Thornley, M. J. \& Sharpe, M. E. (1959). Micro-organisms from chicken meat related to both lactobacilli and aerobic spore formers. J. appl. Bact. 22, 368.

VANKOVA, J. (1957). Motile catalase-producing strains of Lactobacillus delbrueckii. Nature, Lond. 179, 204.

Whittenbury, R. (1960). Two types of catalase-like activity in lactic acid bacteria. Nature, Lond. 187, 433. 